\title{
A GUIDE-POST FOR THE SECOND DECADE OF THE BULLETIN OF THE SLOVENIAN ARMED FORCES
}

This updated issue of the professional publication Bulletin of the Slovenian Armed Forces is dedicated to the question of the Slovenian commitment to finding peaceful solutions to conflicts. As Commander-in-Chief of the Defence Forces of the Republic of Slovenia, I find this subject not only necessary but also entirely essential. There are many reasons for this. The historical experience of the Slovenian people has not always been pleasant regarding the preservation of national identity, manifested in the language as well as in the cultural and national tradition. Despite different repressive and denationalising measures taken by many foreign authorities, our ancestors managed to preserve the Slovenian nation through much wisdom, deep national awareness and political skill. The importance of consistent compliance with the provisions of international law in crisis situations, including wars, was seen in 1991. Slovenia won the war, not only in a military sense but also by complying with all legal norms, thus soon becoming recognised as a young European democratic country founded on high legal and moral principles. The lessons of war in 1991 increased the resolve of the Slovenian people for clear rejection of the use of force in finding solutions to any kind of conflict.

For this reason, my pleasure at being invited to write about the topic of Slovenian people in the service of peace is that much greater, in part also due to the fact that I spent a large part of my professional life, from 1992 to 2005, working in the United Nations, first as the ambassador of the Republic of Slovenia, later as UN Assistant Secretary-General. In both functions I dealt with peacekeeping operations to a considerable extent. United Nations peacekeeping operations were in full swing at that time and underwent great development on the one hand, but also bitter disappointment and moments of deep doubt on the other. However, they continued to develop to the current extent. 
The topic of the Bulletin is presented in truly deep, scientific, theoretical and practical ways, from strategic and tactical levels, considering the evolutionary and transformational characteristics of peacekeeping operations, and deriving from historical experience. The most respected authors in the Slovenian professional field have thrown light upon important conceptual changes in the area of peacekeeping operations, which result from numerous factors, in particular from important geopolitical changes in the world. We must not disregard the increasing cooperation of regional organisations in the implementation of peacekeeping operations, which has indirectly brought about a different understanding of the term "peacekeeping operation" and opened technical discussions in the area of terminology as well as in the technical fulfilment of obligations, all the way to the question of the necessity of a preliminary UN mandate. These deficiencies can also be seen in Slovenia and point to the need for conducting a deep technical discussion as soon as possible and unifying the understanding of both the structure of the Slovenian Armed Forces and the broader defence and security system. The introductory and in particular the more theoretical parts of the Bulletin may be taken as important contributions in this regard.

Some of the articles offer interesting historical insight into the cooperation of Slovenian men, and later women, in various endeavours for peace launched by individual great powers and international organisations. Although it is difficult to understand the military intervention of European forces on the island Crete in 1897 as a peacekeeping operation, the objective which is still in the forefront of contemporary efforts of the international community in this area was achieved for at least some time. This intervention ensured an armistice between the parties involved in the conflict and enabled a diplomatic solution on the island without unnecessary victims. The confidence that the highest political and military authorities in the Austro-Hungarian Empire had in the $2^{\text {nd }}$ Battalion of the $87^{\text {th }}$ Infantry Regiment from Celje was truly special. This was particularly the case because the military unit was mainly composed of Slovenes, and at the time of deployment in Crete its commander was a Slovene as well. However, we need to emphasise that such thinking is unconventional. By studying the literature on peacekeeping operations we see that such operations were first mentioned around 1919 in connection with peace conferences after the end of World War I and with managing various border issues in Europe, different plebiscites and other situations which, besides political and other diplomatic action, also required the protection of security and were followed by military operations intended for this particular purpose.

History tells us much about peacekeeping operations intended to maintain truces. In these operations, coalition forces were deployed to an area in which a truce already existed and had to be maintained among well organised and disciplined armed forces. Today, the status of armed forces is quite different. We have to look at all of history and every aspect of international military engagement which is not armed combat by nature but a military presence with various aspects of employment of military force and the constant readiness and capability of peace forces to defend themselves 
effectively and be prepared to use weapons to fulfil their mandate. If today we see peacekeeping operations as valid in this respect, it is clear that we have to be familiar with history and evaluate what we can learn from past experience and how we are obliged to consider the present.

Of course, we must consider the present. If we look at the status of peacekeeping operations today, we see how important this military activity is for the modern world. I will only dwell upon the United Nations, which from the standpoint of peacekeeping operations is the most important organisation operating today. Approximately 140,000 soldiers participate in peacekeeping operations under the auspices of the United Nations. No other military force has that number of uniformed personnel operating abroad. These people are assigned to eighteen currently active peacekeeping operations, each costing the organisation about seven billion dollars. This is the largest component of the budget of the United Nations. However, this expenditure is small in comparison to other kinds of military deployment outside the $\mathrm{UN}$, to operations which are not peacekeeping operations by nature.

Peacekeeping operations have become very multidimensional. The latest such operations, established in Africa (Darfur, Chad, Central African Republic), have been among the most demanding from the very beginning. We can thus conclude that peacekeeping operations are becoming increasingly more complex, which also results in a higher degree of risk. In 2007, 67 members of UN peacekeeping operations lost their lives. Looking at individual operations we see that six people died in Lebanon alone that year. Ever since peacekeeping operations have been in existence, Lebanon has been one of the most dangerous areas. Today, however, it is somewhat outside the sphere of interest. This may be due to the fact that there is a peacekeeping operation active in the area, on account of which a state of relative peace can be better maintained.

Peacekeeping operations are both dangerous and multidimensional, multidimensional because they are no longer focused merely on keeping belligerent parties apart. Modern peacekeeping operations include both standard and supplemental functions. Providing a secure environment for political normalisation, humanitarian activity and development is a comprehensive task, requiring the engagement of peacekeeping forces in operations that are far from being common types of military deployment. This raises different questions about the training and competence of peacekeeping forces. We also have to ask ourselves how we can fully consider the lessons learned from previous peacekeeping operations and organise a system of command, particularly in organisations such as the United Nations, while at the same time making sure that national contingents do not lose their identity. There are thus two lines of communication, one through channels established by international organisations and the other through those established by national systems of armed forces. How to balance this and achieve efficient functioning? How to ensure the operation of different cultures, members and levels of competence in a way that facilitates the success of peacekeeping operations? These are always important questions to consider. 
In recent years the question of interest has pointed to the complexity of modern peacekeeping operations. Peacekeeping operations are frequently required to facilitate an environment in which elections can be conducted and assist in the establishment of a legal order and institutions to maintain that order. Both tasks are extremely demanding. The establishment of a safe environment for conducting elections in a country with poor communications, with no tradition of elections and with violence linked to every political event, is an extremely difficult task. The establishment of a legal order in areas with no such tradition or adequate infrastructure is even harder. There is often a need to include the civilian police, whose tasks in peacekeeping operations are very demanding. Civilian police have a number of other particularities besides problems connected to the aforementioned multidimensionality. It is necessary to adapt to the local environment in order to facilitate effective police performance. How to facilitate this in an environment such as Haiti, for example, with its difficult past? How to facilitate this in linguistically demanding environments such as East Timor until recently and in other difficult circumstances?

These are all extremely demanding tasks. However, there is not much understanding with regard to all the details and problems arising from their implementation. The international political community is often satisfied merely by defining the mandate of a peacekeeping operation. For many people this signifies the solution to the problem, considering that the mandate is defined and that the deployment of forces will occur. However, this is where real problem solving only begins. Only then does it become obvious what little meaning general resolutions of the United Nations Security Council and other acts by which mandates are defined have in the context of actual situations. Therefore, I am of the opinion that we have to take a detailed look at experience from the distant past as well as the present.

When speaking of the civilian police we also have to consider the fully human aspects that characterise every peacekeeping operation. Once I spoke to a very experienced leader of civilian police operations about the need to send additional police officers to the mission in Kosovo in the spring, when winter is over and people become more active, which also results in a higher crime rate. He explained that this is not only a problem in the area of this mission but elsewhere in Europe. In spring, the crime rate rises everywhere. Therefore it is difficult to find police officers during this time who are willing to leave their homeland, where they are most needed, and go to a mission area which is just then facing increased needs. I mention this to broaden understanding of the fact that the deployment of peacekeeping forces, both military and civilian police, is not only a matter of mandates and military organisation, but sometimes of the purely elementary questions that accompany social development.

I have already mentioned that memory of the past is a very important component of considering present peacekeeping operations. I would like to conclude with another thought. I believe the manner of organising the knowledge of peacekeeping operations is of great importance to all countries, especially those that are new to 
cooperating in peacekeeping operations. This knowledge cannot be gained from books written at universities, but only from monitoring and carefully analysing the previous experiences of others. It is very important that this knowledge be carefully organised, that these experiences be carefully gathered and analysed, and that a doctrine be developed gradually. This doctrine is required for a country like Slovenia, which is new at conducting peacekeeping operations, to be able to manage well and define its role in international peacekeeping operations properly. To achieve this objective, a new country must cooperate with those countries which have been conducting peacekeeping operations for a long time and therefore have a richer experience. The neighbouring Austria is known to have one of the longest and most interesting systems of experience in peacekeeping operations within the United Nations. Ever since it joined the UN, Austria has been active in numerous activities linked to peacekeeping operations. Its soldiers and the civilian police have participated in a number of peacekeeping operations. Experience gained in this way is of great value, and using this experience is necessary for successful planning of and operating in future peacekeeping operations.

The future will be complicated! At one time, when the members of peacekeeping operations numbered approximately 80,000, the United Nations thought that nothing more could be done, and a larger number of members was unthinkable. Today the number of members is significantly larger, development will most likely still continue and conditions will become even more demanding. I do not wish to forecast events which have not yet taken place. However, I would like to strongly emphasise that the history of peacekeeping operations is not over yet and that the future will be full of risks and challenges.

I would also again like to stress the importance of this issue of the Bulletin of the Slovenian Armed Forces, which is entering a new decade, and express my pleasure at being able to note down a few thoughts. Let me particularly emphasise that as Commander-in-Chief of the Slovenian Defence Forces I will continue to devote special attention to achievements in the area of cooperation in peacekeeping operations in the future, having a special interest in these experiences. I thank the authors of the articles of this important issue of the Bulletin for their scientific and professional contributions - and I greatly respect those who have already done important work in the name of the Republic of Slovenia with the Slovenian flag on their shoulders, with the hope that they continue to fulfil their obligations in accordance with the rules. 